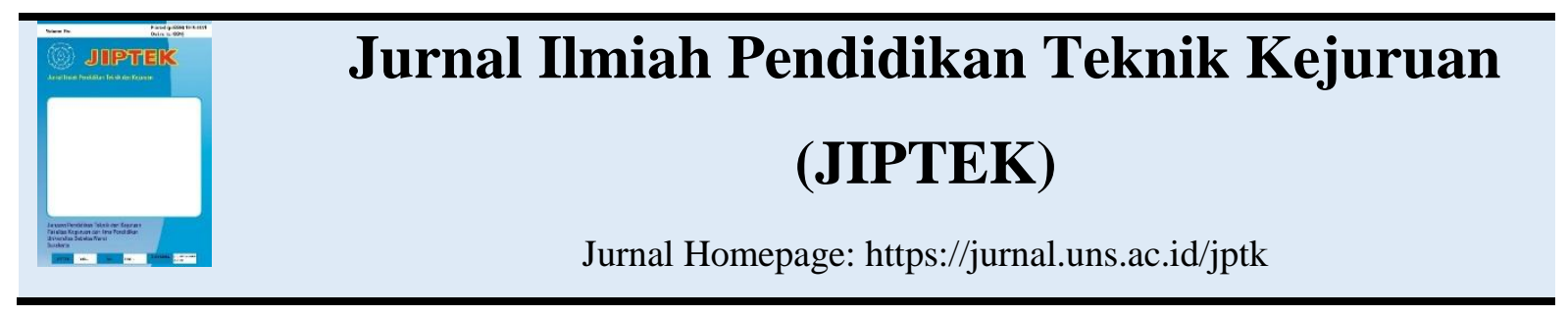

\title{
PERANCANGAN MEDIA PEMBELAJARAN BERBASIS VIDEO TUTORIAL PADA MATA KULIAH ILMU UKUR TANAH II
}

\author{
Arif Sofarul Anwar, Sukatiman, Abdul Haris Setiawan \\ Program Studi Pendidikan Teknik Bangunan, FKIP, Universitas Sebelas Maret Surakarta \\ Jalan Ahmad Yani 200 Surakarta \\ Email: sukatiman@staff.fkip.uns.ac.id
}

\begin{abstract}
ABSTRAK
Tujuan Penelitian ini adalah : (1) Merancang media pembelajaran berbasis video tutorial pada mata kuliah Ilmu Ukur Tanah II. (2) Mengetahui tingkat kelayakan media pembelajaran berbasis video tutorial pada mata kuliah Ilmu Ukur Tanah II. Penelitian ini merupakan penelitian Research \& Development $(R \& D)$ melalui prosedur pengembangan media pembelajaran yaitu : (1) Tahap studi pendahuluan dengan melaksanakan studi lapangan dan studi literatur. (2) Tahap studi perancangan dengan melakukan penyusunan desain media yang dibagi menjadi 3 bagian diantaranya: penyusunan draft materi, penyusunan naskah materi, penyusunan storyboard dan penentuan kebutuhan software dan hardware. Kemudian pengambilan video, screenshoot video, editing video, dubbing audio dan penyusunan dalam adobe flash professional cs6. Selanjutnya melakukan validasi penilaian kepada para ahli / pakar materi, media dan pembelajaran untuk menilai kelayakan media pembelajaran. Selanjutnya melakukan uji coba terbatas dengan 8 mahasiswa yang pernah menempuh mata kuliah ilmu ukur tanah II dan uji coba luas kepada 54 mahasiswa PTB FKIP UNS yang pernah menempuh mata kuliah ilmu ukur tanah II. (3) Tahap evaluasi merupakan tahap akhir dari proses perancangan terkait model final media pembelajaran mata kuliah ilmu ukur tanah II. Berdasarkan hasil penelitian dari penilaian ahli materi menyatakan bahwa media pembelajaran ilmu ukur tanah II sangat layak digunakan dengan persentase sebesar 90\%. Penilaian ahli media menyatakan bahwa perancangan media pembelajaran ilmu ukur tanah II termasuk kategori sangat layak dengan persentase $98,5 \%$. Penilaian ahli pembelajaran menyatakan bahwa perancangan media pembelajaran ilmu ukur tanah II sangat layak dengan persentase sebesar $92 \%$ sedangkan uji coba terbatas hasil yang diperoleh sebesar $82,5 \%$ menyatakan bahwa media pembelajaran yang dirancang sangat layak kemudian pada uji coba luas menyatakan dengan persentase $79 \%$ bahwa media pembelajaran termasuk kategori layak.
\end{abstract}

Kata Kunci: media pembelajaran, ilmu ukur tanah II, video tutorial 


\section{PENDAHULUAN}

Perkembangan teknologi dan informasi di Indonesia dewasa ini menunjukan indeks cukup signifikan yang membawa dampak terhadap berbagai bidang dalam kehidupan sehari-hari. Misalnya pada bidang ekonomi, dengan ditetapkannya Masyarakat Ekonomi Asean (MEA)/AEC (Asean Economic Community) 2015, masyarakat indonesia dituntut untuk turut mengikuti perkembangan teknologi dan informasi tersebut sebagai upaya bersaing dengan Negara anggota ASEAN lainnya.

Seperti yang di terbitkan berita harian Online Warta Ekonomi, Direktur Human Capital and General Affairs PT. Telkom Priyantono Rudito menyatakan bahwa, "Persaingan usaha semakin ketat saat memasuki MEA 2015. Peningkatan kapasitas SDM merupakan sebuah keharusan dan pembelajaran dengan sistem digital akan menjadi solusi menghadapi bergulir Masyarakat Ekonomi ASEAN (MEA)," Rabu (24/9/2014). Pernyataan tersebut secara tidak langsung memiliki hubungan dengan bidang pendidikan yang memberikan tugas besar dalam meningkatkan kualitas pembelajaran di perguruan tinggi.

Berdasarkan Permenristek No. 13 Tahun 2015 (Peraturan Menteri Riset, Teknologi, dan Pendidikan Tinggi), menyebutkan tujuan strategis dalam meningkatkan relevansi, kuantitas dan kualitas sumber daya manusia berpendidikan tinggi, serta kemampuan Iptek dan inovasi untuk keunggulan daya saing bangsa, dijabarkan dalam 5 (lima) sasaran strategis sesuai dengan permasalahan-permasalahan yang harus diselesaikan dalam kurun waktu 2015-2019. Sasaran strategis tersebut adalah: 1) meningkatnya kualitas pembelajaran dan kemahasiswaan pendidikan tinggi, 2) meningkatnya kualitas kelembagaan Iptek dan pendidikan tinggi, 3) meningkatnya relevansi, kualitas, dan kuantitas sumber daya Iptek dan pendidikan tinggi, 4) meningkatnya relevansi dan produktivitas riset dan pengembangan, dan 5) menguatnya kapasitas inovasi.

Sehubungan dengan peraturan tersebut, komponen Lembaga Pendidikan Tenaga Kependidikan (LPTK) sebagai salah satu wadah peningkatan kualitas sumber daya manusia memiliki peran yang sangat besar melalui kegiatan pembelajaran yang dilaksanakan. Mata kuliah Ilmu Ukur Tanah II merupakan bagian dari mata kuliah yang wajib ditempuh oleh mahasiswa Pendidikan Teknik Bangunan. Mata kuliah tersebut, memiliki bobot 3 SKS (Satuan Kredit Semester) yang terdiri dari kegiatan pembelajaran materi dan praktik. Mata kuliah ini adalah mata kuliah lanjutan dari mata kuliah Ilmu Ukur Tanah I. Pada dunia teknik sipil, ilmu ukur tanah merupakan ilmu dasar yang perlu dimiliki oleh praktisi 
konstruksi maupun mahasiswa dalam melakukan kegiatan konstruksi. Pembelajaran yang sering dilaksanakan dalam mata kuliah ini, mahasiswa diberikan penjelasan oleh dosen dengan menggunakan media ajar yang berbentuk modul atau petunjuk praktik Ilmu Ukur Tanah II.

Berdasarkan observasi yang telah dilakukan, proses memahami panduan dan tingkat pemahaman mahasiswa berbedabeda. Hal ini dapat dilihat dari nilai mahasiswa dari salah satu angkatan program studi pendidikan teknik bangunan yang masih banyak di bawah batas standar nilai ketuntasan, dari jumlah mahasiswa sebanyak 62 mahasiswa, hanya 26 mahasiswa atau $41,93 \%$ yang mampu mencapai batas nilai ketuntasan. Masalah inilah yang menjadi pekerjaan rumah bagi peneliti untuk dapat membantu proses pembelajaran lebih efektif dan komunikatif. Selain adanya permasalahan tersebut, penyelesaian pembelajaran yang dilaksanakan mengalami keterlambatan.

Berawal dari munculnya permasalahan tersebut maka perlu dilakukan tindakan yang tepat. Permasalahan waktu yang minim dan rendahnya pemahaman mahasiswa dapat diselesaikan dengan penggunaan media yang mendukung.

Pendekatan pembelajaran dengan menggunakan video memberikan kesempatan kepada mahasiswa untuk belajar secara mandiri sesuai dengan percepatan pembelajaran masingmasing. Video sebagai alat atau sarana pembelajaran yang berisi materi, metode, batasan-batasan, dan cara mengevaluasi yang dirancang secara sistematis dan menarik untuk mencapai kompetensi yang diharapkan. Tutorial atau tutoring adalah bantuan atau bimbingan belajar yang bersifat akademik oleh tutor kepada mahasiswa (tutee) untuk membantu kelancaran proses belajar mandiri mahasiswa secara perorangan atau kelompok berkaitan dengan materi ajar. Tutorial dilaksanakan secara tatap muka atau jarak jauh berdasarkan konsep belajar mandiri. (Sudjana \& Rivai: 89)

Penggunaan video tutorial dalam mata kuliah ukur tanah II belum pernah digunakan. Maka dari itu, penggunaan media pembelajaran berbasis video tutorial akan lebih membantu dosen (sender) dalam menyampaikan materi pembelajarannya kepada mahasiswa (receiver) agar lebih mudah memahami materi secara mandiri di luar jam perkuliahan.

Tujuan dari penelitian ini adalah untuk merancang media pembelajaran berbasis video tutorial pada diharapkan dapat membantu proses pembelajaran mata kuliah Ilmu Ukur Tanah II dan selanjutnya dilakukan mengetahui tingkat kelayakan media pembelajaran berbasis video tutorial pada mata kuliah Ilmu Ukur Tanah II.

Menurut Arsyad (2004: 6) menyatakan bahwa "media pembelajaran 
sering digantikan dengan istilah-istilah seperti alat pandang dengar, bahan pengajaran (instructional material), komunikasi pandang dengar (audio-visual communication), pendidikan alat peraga pandang (visual education), teknologi pendidikan (educational technology), alat peraga dan media penjelas. Dari uraian diatas dapat disimpulkan media pembelajaran merupakan alat untuk menyampaikan informasi belajar serta merangsang pikiran dengan memanfaatkan kemajuan teknologi dan informasi, sehingga mahasiswa mampu memahami materi yang disampaikan oleh dosen dengan lebih mudah dan efisien.

Menurut Abdulhak dan Darmawan (2012: 47) menyatakan bahwa pembelajaran multimedia pada dasarnya merupakan pembelajaran yang diharapkan mampu memberdayakan semua aktivitas otak selama peserta didik melakukan aktivitas pembelajaran.

Video merupakan suatu medium yang sangat efektif untuk membantu proses pembelajaran, baik untuk pembelajaran masal, individual, maupun untuk berkelompok (Daryanto, 2012: 86). Berdasarkan pendapat diatas dapat diambil kesimpulan video tutorial adalah rangkaian gambar hidup yang ditayangkan oleh seorang pengajar baik tatap muka maupun secara mandiri yang berisi pesan-pesan pembelajaran untuk membantu pemahaman terhadap suatu materi pembelajaran sebagai bimbingan atau bahan pengajaran tambahan kepada individu maupun sekelompok peserta didik. Media video tutorial tepat digunakan karena mahasiswa dapat lebih memahami langkah-langkah praktek dan pengolahan data mata kuliah ilmu ukur tanah II.

\section{METODE}

Penelitian ini mengacu pada Research and Development $(R \& D)$ atau metode penelitian dan pengembangan. Metode penelitian dan pengembangan adalah metode penelitian yang digunakan untuk menghasilkan produk tertentu, dan menguji keefektifan produk tersebut (Sugiyono, 2014: 297).

Data penelitian diperoleh dari hasil observasi, dokumentasi, dan angket penilaian media pembelajaran.

Sumber data diperoleh dari mahasiswa, dosen pengampu mata kuliah ilmu ukur tanah II dan dosen ahli.

Teknik pengumpulan data penelitian ini meliputi: observasi, dokumentasi, angket penilaian media. Menurut Sukmadinata (2010: 220) “Observasi (observation) atau pengamatan merupakan suatu teknik atau cara mengumpulkan data dengan jalan mengadakan pengamatan terhadap kegiatan yang sedang berlangsung". Dokumentasi adalah cara pengumpulan data yang dapat berupa foto, rekaman maupun dokumen lain. Angket dalam penelitian digunakan sebagai 
uji kelayakan untuk para ahli dan sebagai tanggapan mahasiswa tentang media pembelajaran berbasis video tutorial. Responden yang dilibatkan dalam pengambilan data adalah ahli materi, ahli media, ahli pembelajaran untuk uji validasi media video tutorial dan Mahasiswa Pendidikan Teknik Bangunan FKIP UNS.

Penelitian ini dianalisis secara statistik deskriptif untuk mendapatkan hasil penelitian pengembangan. Kategori kelayakan media pembelajaran ini dipakai skala pengukuran skala likert. Jawaban setiap item instrumen yang menggunakan skala likert mempunyai gradasi dari sangat positif sampai sangat negatif (Sugiyono, 2013: 135).

\section{HASIL PENELITIAN DAN PEMBAHASAN}

Hasil penelitian perancangan media pembelajaran berbasis video tutorial pada mata kuliah ilmu ukur tanah II dikembangkan berdasarkan prosedur yang telah dirancang. Dalam pelaksanaannya, penelitian ini terbagi menjadi 3 tahap yaitu :

\section{a) Tahap Studi Pendahuluan}

Dalam studi pendahuluan, terbagi menjadi studi, yaitu : studi lapangan dan studi literatur. Studi lapangan dilaksanakan untuk mengumpulkan data, menggali permasalahan dan mengidentifikasi masalah. Studi lapangan dilakukan pada mahasiswa angkatan 2013 yang telah mengambil mata kuliah Ilmu Ukur Tanah II dan Dosen Pengampu Mata Kuliah Ilmu ukur tanah II. Dari hasil observasi melalui wawancara personal yang telah dilakukan didapatkan bahwa mahasiswa dalam melaksanakan praktik ilmu ukur tanah II belum memiliki persiapan praktik ilmu ukur tanah II yang mengakibatkan mahasiswa mengalami kesulitan memahami materi saat dosen memberi petunjuk sebelum praktik dan berujung pada keterlambatan proses pembelajaran praktik.

Studi literatur atau studi pustaka merupakan kajian untuk mempelajari konsep-konsep atau teori-teori yang berkenaan dengan produk atau model yang dirancang. Pada tahap ini didapatkan konsep yang berupa acuan dari penelitian relevan sebelumnya yang tersusun dalam kajian teori. Sedangkan materi-materi mata kuliah ilmu ukur tanah II didapatkan dari sumber bahan ajar pada media pembelajaran video tutorial. Hasil dari studi literatur dapat dilihat pada sumber belajar silabus mata kuliah ilmu ukur tanah II.

\section{b) Tahap Studi Perancangan}

Penyusunan desain media adalah awal dari studi perancangan dengan menyusun draft materi mata kuliah ilmu ukur tanah II yang mengacu pada silabus. Penyusunan draft materi dilakukan bersama dosen pengampu mata kuliah ilmu ukur tanah. Selanjutnya, penyusunan naskah materi digunakan untuk menjelaskan isi materi 
dalam media pembelajaran berbasis video tutorial, penyusunan storyboard yang berupa keterangan visual yang disusun berurutan sesuai dengan naskah, selanjutnya menentukan kebutuhan software dan hardware.

Tahap selanjutnya yaitu pengambilan video. Pada proses pengambilan video dilakukan pada tanggal 17,28 April 2016 dan 6 Juni 2016 di Lingkungan Kampus V UNS dengan mempraktikan langsung pengenalan alat total station, pengukuran poligon tertutup, situasi, dan kontur.

Selanjutnya melakukan screenshoot video menggunakan aplikasi camtasia studio 8. Pada saat yang sama, tampilan pada layar monitor akan direkam dengan bantuan program camtasia studio 8 sebagai program perekam aktifitas yang tampak dalam tampilan layar monitor.

Program camtasia studio 8 juga sekaligus merekam narasi yang dibacakan peneliti saat membuat video pengolahan data, ilustrasi materi, maupun penggambaran hasil praktik mata kuliah ilmu ukur tanah II.

Editing video bertujuan untuk mengolah hasil pengambilan video praktik, tangkapan layar dan rekaman suara agar menjadi sebuah video yang siap untuk di susun berupa media pembelajaran berbasis video tutorial.

Video yang sudah selesai di rangkai kemudian dikemas dengan program Adobe
Flash Professional CS6. Berikut tampilan dalam media pembelajaran yang telah dirancang :

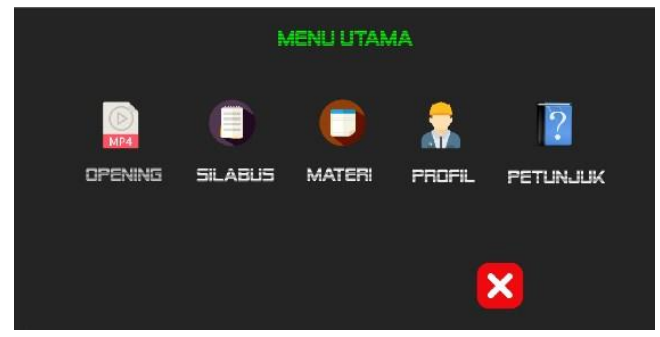

Gambar 1. Menu Utama

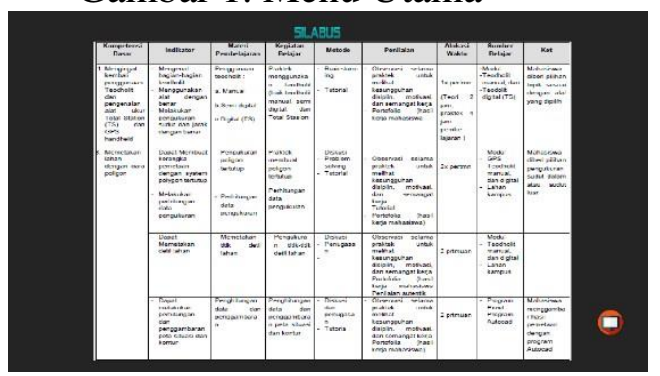

Gambar 2. Tampilan Silabus

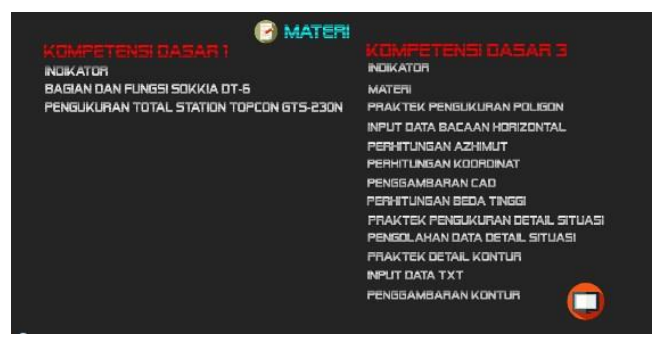

Gambar 3. Menu Materi

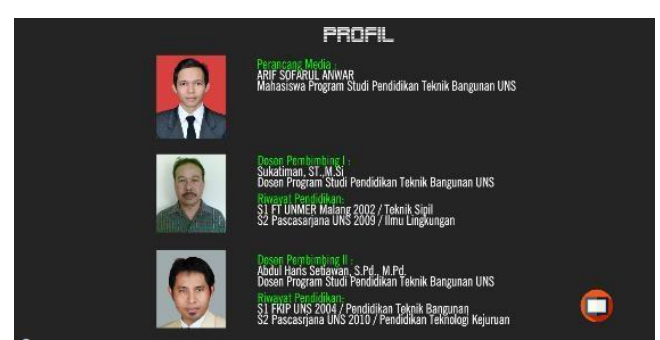

Gambar 4. Tampilan Profil

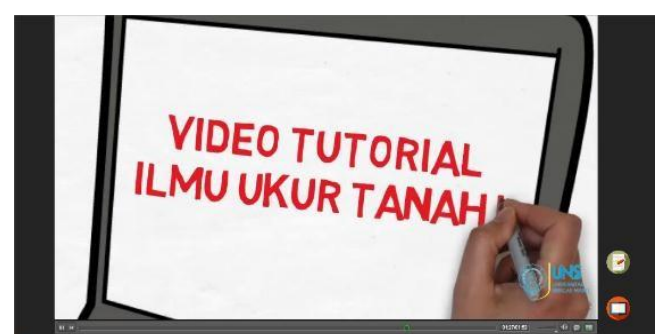

Gambar 5. Tampilan Video Opening 


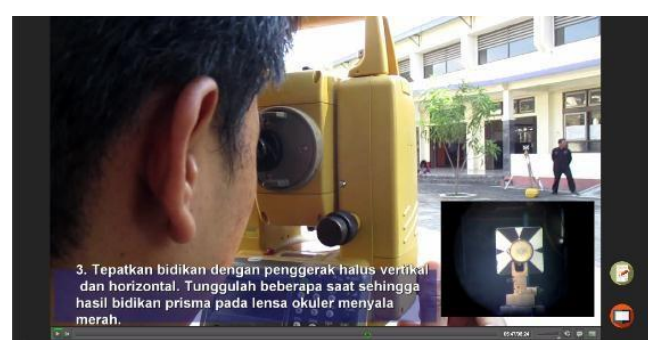

Gambar 6. Tampilan Video Pengukuran dengan Total Station

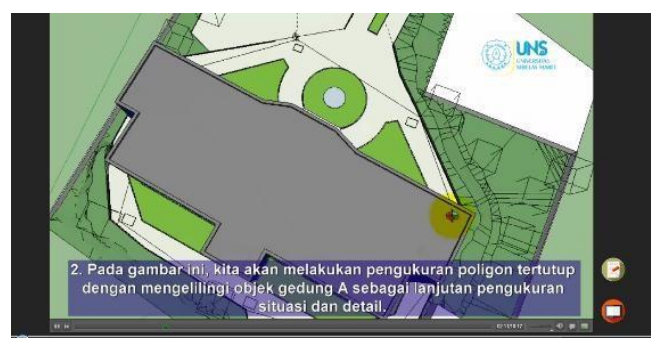

Gambar 7. Tampilan Animasi Poligon Tertutup

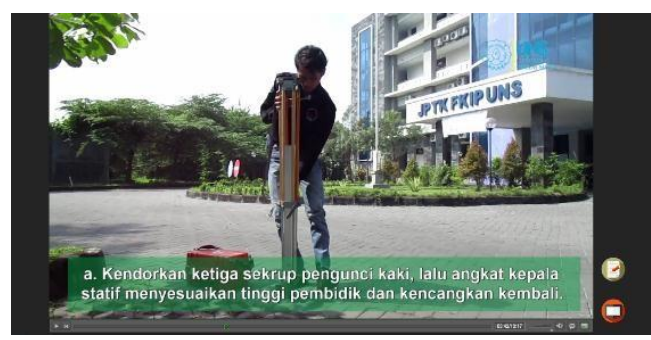

Gambar 8. Tampilan Video Pengukuran Poligon

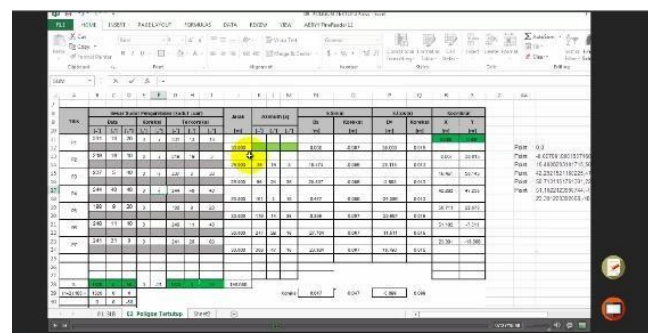

Gambar 9. Tampilan Perhitungan

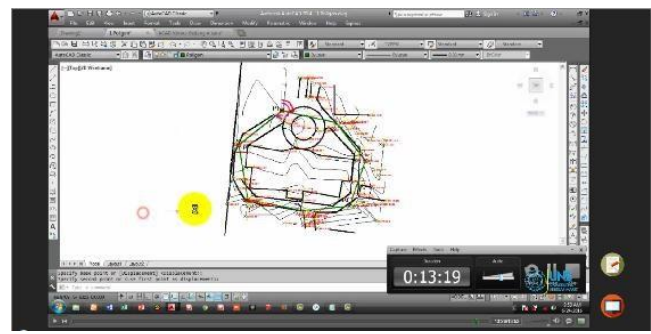

Gambar 10. Tampilan Penggambaran AutoCAD
Setelah dilakukan pembuatan media, kemudian dilakukan tahap validasi tim ahli dan uji coba. Tahap ini bertujuan untuk menguji kelayakan media pembelajaran video tutorial oleh 1 ahli media, 1 ahli materi, 1 ahli pembelajaran dan 8 mahasiswa pada uji coba terbatas dan 54 mahasiswa pada uji coba luas angkatan 2013 dan 2014 FKIP UNS yang telah mengambil mata kuliah Ilmu Ukur Tanah II.

Tabel 1. Penilaian media oleh Ahli Materi

\begin{tabular}{clc}
\hline 1 & $\begin{array}{l}\text { Relevansi materi-materi } \\
\text { Mengenai bagian-bagian } \\
\text { teodholoit } \\
\text { (Sokkia DT6) }\end{array}$ & $88 \%$ \\
\hline 2 & $\begin{array}{l}\text { Relevansi materi } \\
\text { Menggunakan alat dengan } \\
\text { benar (Total } \\
\text { Station) }\end{array}$ & \\
\hline 3 & $\begin{array}{l}\text { Relevansi materi } \\
\text { melakukan pengukuran } \\
\text { sudut dan jarak (Total }\end{array}$ & \\
& Station) \\
\hline 4 & $\begin{array}{l}\text { Relevansi materi } \\
\text { membuat kerangka } \\
\text { pemetaan dengan sistem } \\
\text { poligon tertutup }\end{array}$ \\
\hline 5 & $\begin{array}{l}\text { Relevansi Materi } \\
\text { melakukan perhitungan } \\
\text { data pengukuran }\end{array}$ \\
\hline 6 & $\begin{array}{l}\text { Relevansi materi } \\
\text { memetakan } \\
\text { detil lahan }\end{array}$ \\
\hline 7 & $\begin{array}{l}\text { Relevansi } \\
\text { materi melakukan } \\
\text { perhitungan dan } \\
\text { penggambaran } \\
\text { peta situasi dan kontur }\end{array}$ \\
\hline Total & $92 \%$ \\
\hline & $92 \%$ \\
\hline
\end{tabular}


Pada Tabel 1. menampilkan hasil pengujian oleh ahli materi memiliki ratarata penilaian sebesar 90\%. Angka 90\% ini didapat dari rata-rata penilaian per aspek dari ahli materi. Media pembelajaran dikatakan sangat layak jika memiliki penilaian antara $81 \%-100 \%$. Sehingga dari aspek materi, media pembelajaran yang telah dikembangkan masuk dalam kategori sangat layak digunakan dalam proses pembelajaran mata kuliah ilmu ukur tanah II.

Tabel 2. Penilaian Media oleh Ahli Media

\begin{tabular}{clc}
\hline No. & \multicolumn{1}{c}{ Aspek } & $\begin{array}{c}\text { Skor } \\
(\mathbf{\%})\end{array}$ \\
\hline 1. & Mutu Teknis & $94 \%$ \\
\hline$\underline{2 .}$ & $\underline{\text { Komposisi }}$ & $\underline{100 \%}$ \\
$\underline{\text { 3. }}$ & $\underline{\text { Keseimbangan }}$ & $\underline{100 \%}$ \\
$\underline{4 .}$ & $\frac{\text { Keterpaduan }}{\text { Total }}$ & $\underline{\mathbf{1 0 0 \%}}$ \\
\hline
\end{tabular}

Pada Tabel 2. hasil pengujian oleh ahli media memiliki rata-rata penilaian sebesar 98,5\%. Angka 98,5\% ini didapat dari ratarata penilaian per aspek dari ahli media. Media pembelajaran dikatakan sangat layak jika memiliki penilaian antara $81 \%-100 \%$. Sehingga dari aspek media, media pembelajaran yang telah dikembangkan masuk dalam kategori sangat layak digunakan dalam proses pembelajaran mata kuliah ilmu ukur tanah II.
Tabel 3. Penilaian Media oleh Ahli Pembelajaran

\begin{tabular}{lll}
\hline No. & Aspek & Skor $(\mathbf{\%})$ \\
\hline 1. & Tujuan & $100 \%$ \\
\hline 2. & Ketepatgunaan & $85 \%$ \\
\hline 3. & Mutu Teknis & $91 \%$ \\
\hline 4. & Tingkat & $96 \%$ \\
& Kemampuan & \\
& Mahasiswa & \\
\hline $\mathbf{5}$ & Manfaat & $91 \%$ \\
\hline & Total & $\mathbf{9 2 \%}$
\end{tabular}

Pada Tabel 3. hasil akhir pengujian oleh ahli pembelajaran memiliki rata-rata penilaian sebesar 92\%. Angka 92\% ini didapat dari rata-rata penilaian per aspek. Media pembelajaran dikatakan sangat layak jika memiliki penilaian antara $81 \%-100 \%$. Sehingga dari penilaian uji kelayakan oleh ahli pembelajaran, media pembelajaran yang telah dikembangkan masuk dalam kategori sangat layak digunakan dalam proses pembelajaran mata kuliah ilmu ukur tanah II.

Tabel 4. Rekapitulasi Uji Coba Terbatas

\begin{tabular}{lll}
\hline No. & Aspek & Skor $(\boldsymbol{\%})$ \\
\hline 1. & Kesederhanaan & $83 \%$ \\
\hline 2. & Kejelasan & $78 \%$ \\
\hline 3. & Kemudahan & $79 \%$ \\
\hline 4. & Edukatif & $83 \%$ \\
\hline 5. & Daya Tarik & $86 \%$ \\
\hline & Total & $82,5 \%$ \\
\hline
\end{tabular}

Pada Tabel 4. hasil rekapitulasi tanggapan mahasiswa uji coba terbatas dengan jumlah 8 mahasiswa memiliki ratarata penilaian sebesar $82,5 \%$, dan dapat diketahui bahwa secara keseluruhan siswa memberikan tanggapan positif terhadap media pembelajaran video tutorial mata 
kuliah ilmu ukur tanah II. Persentase tanggapan mahasiswa ini sudah memenuhi indikator keberhasilan yang ingin dicapai, yaitu $\geq 81 \%$, sehingga media pembelajaran yang telah dirancang dikatakan sangat layak.

Tabel 5. Rekapitulasi Uji Coba Luas

\begin{tabular}{lll}
\hline No. & Aspek & Skor $(\%)$ \\
\hline 1. & Kesederhanaan & $79 \%$ \\
\hline 2. & Kejelasan & $76 \%$ \\
\hline 3. & Kemudahan & $78 \%$ \\
\hline 4. & Edukatif & $77 \%$ \\
\hline 5. & Daya Tarik & $82 \%$ \\
\hline & Total & $\mathbf{7 9 \%}$
\end{tabular}

Pada Tabel 5. hasil rekapitulasi tanggapan mahasiswa uji coba luas dengan jumlah 54 mahasiswa memiliki rata-rata penilaian sebesar $79 \%$, dan dapat diketahui bahwa secara keseluruhan siswa memberikan tanggapan positif terhadap media pembelajaran video tutorial mata kuliah ilmu ukur tanah II. Persentase tanggapan mahasiswa ini sudah memenuhi indikator layak.

\section{c) Tahap Evaluasi}

Dalam tahap ini, media pembelajaran yang telah divalidasi oleh ahli materi, media dan pembelajaran yang berupa model final kemudian diterapkan kepada pengguna atau mahasiswa. Hasil akhir ini berupa media pembelajaran video tutorial yang siap untuk digunakan pada mata kuliah ilmu ukur tanah II.

\section{KESIMPULAN}

Berdasarkan hasil penelitian dan pembahasan penelitian pengembangan ini dapat ditarik kesimpulan sebagai berikut: 1) Prosedur perancangan media pembelajaran berbasis video tutorial pada mata kuliah ilmu ukur tanah II, dengan kompetensi dasar I dan III, meliputi beberapa tahap yaitu: (a) tahap studi pendahuluan (b) tahap perancangan (c) tahap evaluasi. 2) Kelayakan media pembelajaran berdasarkan pakar ahli materi dengan skor sebesar $90 \%$ (sangat layak), berdasarkan pakar ahli media dengan skor sebesar 98,5\% (sangat layak), dan berdasarkan pakar ahli pembelajaran dengan skor sebesar 92\% (sangat layak). 3) Kelayakan uji coba terbatas terhadap media pembelajaran berdasarkan pendapat 8 mahasiswa PTB FKIP UNS diperoleh skor sebesar $82,5 \%$ (sangat layak). Kelayakan uji coba luas terhadap media pembelajaran berdasarkan pendapat 54 mahasiswa PTB FKIP UNS mendapatkan rata-rata skor sebesar 79\% (layak).

\section{SARAN}

Berdasarkan hasil penelitian pengembangan yang telah dilaksanakan, maka ada beberapa saran yang dikemukakan yaitu: Dikarenakan produk media pembelajaran berupa $D V D$ maka spesifikasi komputer dan laptop setidaknya mempunyai 
DVD rom agar media pembelajaran dapat digunakan.

Media pembelajaran berbasis video tutorial ini hanya sebagai media pembelajaran guru/ dosen dalam menyampaikan materi dan langkahlangkah, sehingga tetap perlu adanya penggabungan metode-metode lain dalam pembelajaran.

Produk yang dihasilkan hanya mengembangkan mata kuliah Ilmu Ukur Tanah II pada kompetensi dasar I dan III sehingga diharapkan peneliti selanjutnya untuk menciptakan pengembangan lanjut pada materi yang lebih lengkap.

Diharapkan dalam pengembangan selanjutnya, peneliti selanjutnya mampu mengetahui peningkatan hasil belajar mahasiswa dengan membandingkan hasil pre test dan post test.

\section{DAFTAR PUSTAKA}

Abdulhak, I \& Darmawan, D. (2013). Teknologi Pendidikan. Bandung: PT. Remaja Rosdakarya.

Arsyad. A. (2004). Media Pembelajaran (cetakan kelima). Jakarta: Raja Grafindo

Daryanto. (2012). Media Pembelajaran. Bandung: PT. Sarana Tutorial Nurani Sejahtera

(2014). Pembelajaran Sistem Digital Solusi MEA. Diperoleh 13 Februari 2016, dari http://wartaekonomi.co.id/re $\mathrm{ad} / 2014 / 09 / 25 / 35595 /$ telkom pembelajaran-sistemdigital-solusihadapimea.html

Permenristek. (2015). Rencana Strategis Kementerian Riset, Teknologi, dan Pendidikan Tinggi tahun 2015-2019. Jakarta: Menteri Riset, Teknologi dan Pendidikan Tinggi Republik Indonesia Sudjana, N. \& Rivai, A. (1990). Media Pengajaran. Bandung: Sinar Baru.

Sugiyono. (2014). Metode Penelitian Kuantitatif Kualitatif dan $R \& D$. Bandung: PT. Alfabeta

Sukmadinata, Nana S. (2010). Metode Penelitian Pendidikan. Cetakan ke-4. Bandung: PT. Remaja Rosdakarya 